\title{
Metallothionein genes in the European flat oyster Ostrea edulis: a potential ecological tool for environmental monitoring?
}

\author{
Arnaud Tanguy ${ }^{1,2}$, Isabelle Boutet ${ }^{2}$, Ricardo Riso ${ }^{3}$, Pierre Boudry ${ }^{4}$, \\ Michel Auffret ${ }^{2}$, Dario Moraga ${ }^{2, *}$ \\ ${ }^{1}$ Haskin Shellfish Research Laboratory, 6959 Miller Avenue, Port Norris, New Jersey 08349, USA \\ ${ }^{2}$ Laboratoire des Sciences de l'Environnement Marin (LEMAR), UMR CNRS 6539, Institut Universitaire Européen de la Mer, \\ Université de Bretagne Occidentale, Technopôle Brest, Iroise, Place Nicolas Copernic, 29280 Plouzané, France \\ ${ }^{3}$ Laboratoire de Chimie Marine UBO et UPR CNRS 9042 (Roscoff), Institut Universitaire Européen de la Mer, \\ Place Nicolas Copernic, 29280 Plouzané, France \\ ${ }^{4}$ Laboratoire de Génétique et Pathologie, IFREMER La Tremblade, 17390 La Tremblade, France
}

\begin{abstract}
Metallothioneins (MTs) are small essential proteins involved in cellular processes of metal handling and detoxification. Here, we describe the structure of 2 MT genes in a marine mollusc, the European flat oyster Ostrea edulis. The sequences of these 2 genes code for 2 proteins of 74 and 71 amino acids, respectively, with the 71 amino acid protein having an abnormal lack of cysteine residues. The direct quantification of metal ions bound to purified recombinant proteins demonstrated that the metal-binding capacity of the 2 proteins differs by about $20 \%$. An enzyme-linked immunosorbent assay (ELISA) test, used to quantify MT protein expression in O. edulis exposed to metal under laboratory conditions, showed no significant induction of MTs, either in the gills or the digestive gland despite an increase in metal concentration observed in the same tissues. Similar results were observed with an MT-RNA expression study. These results seem to indicate a low involvement of MTs in metal detoxification in O. edulis. Examination of polymorphism in the coding sequence of OeMT $(O$. edulis metallothionein) genes by single-strand conformation polymorphism (SSCP) revealed a lack of genetic diversity in field populations.
\end{abstract}

KEY WORDS: Metallothionein · Detoxification $\cdot$ Expression $\cdot$ ELISA $\cdot$ Polymorphism $\cdot$ Ostrea edulis Resale or republication not permitted without written consent of the publisher

\section{INTRODUCTION}

Oysters and mussels are widespread throughout the world and represent a key element in the ecology and economy of coastal ecosystems. In previous studies we used the Pacific oyster Crassostrea gigas as a biological tool to monitor the heavy metal contamination in coastal ecosystems, and we developed an antibody against metallothioneins (Boutet et al. 2002) and genetic markers on MT genes (Tanguy et al. 2002). In the present study, we chose the flat oyster Ostrea edulis to investigate the possibility of using MT genes in this species as a metal contamination indicator. Met- allothioneins (MTs) are low molecular weight (6 to $7 \mathrm{kDa}$ ) cytoplasmic metal-binding proteins involved in cellular essential metal (copper, zinc) ion regulation and heavy metal (cadmium, mercury) detoxification (Kojima \& Kägi 1978). MTs are also involved in different metabolic processes including the protection of cells against intracellular oxidative damage or free radical scavengers (Karin 1985, Hamer 1986). A large number of MT isoforms have been isolated from vertebrates and invertebrates, apparently originating from events of gene duplication that may have occurred many times independently (Griffith et al. 1983, Hunziker et al. 1995). Although a multiplicity of mammal- 
ian MTs has been described, including 14 in humans (Gedamu et al. 1987) and 9 in sheep (Peterson et al. 1988), only 1 or 2 distinct MTs have been isolated in lower vertebrates (Kägi 1993). In invertebrates, the number of MT variants identified depends on the species: 9 MT isoforms have been characterised in the blue mussel Mytilus edulis (Barsyte et al. 1999), 7 in the sea urchin Strongylocentrotus purpuratus (Nemer et al. 1984, Wilkinson \& Nemer 1987), 1 each in the tropical green mussel Perna viridis (Khoo \& Patel 1999) and the eastern oyster C. virginica (Unger et al. 1991), and 2 in the Pacific oyster C. gigas (Tanguy \& Moraga 2001, Tanguy et al. 2001).

Classically, MT genes are characterised by a structure of 3 coding exons, but some additional non-coding exons have been observed in either the $3^{\prime}$ or $5^{\prime}$ region in invertebrates such as Strongylocentrotus purpuratus (Nemer et al. 1991) or Crassostrea gigas (Tanguy et al. 2001), respectively. These 3 exons code for 2 domains: an $\alpha$-domain that commonly contains 11 cysteine residues and binds 4 bivalent ions, and a $\beta$-domain that contains 9 cysteine residues and binds 3 bivalent ions (Boulanger et al. 1983, Furey et al. 1986).

Several studies carried out on marine invertebrates have characterised MT cDNAs, but few genes have been isolated from molluscs despite their use in monitoring of environmental perturbations. In the European flat oyster Ostrea edulis, only 1 study, based on analysis of proteins, demonstrated the existence of 2 major MT isoforms (Alonso \& Martin-Mateo 1996). In this paper, we characterise the structure of $2 \mathrm{MT}$ genes in Ostrea edulis that present some common features with others MT genes; however 1 possesses a lower number of cysteine residues than expected, leading to a decrease in its metal-binding capacity. We also investigated the expression of $O$. edulis MT genes in metal contamination experiments using a polyclonal antibody for protein quantification and polymerase chain reaction (PCR) for RNA, and we compare the results to those obtained for other species. A preliminary study of polymorphism using single-strand conformation polymorphism (SSCP) analysis was also conducted on the coding sequence of the OeMT genes to potentially characterize new genetic markers in relation to heavy metal tolerance in this species.

\section{MATERIALS AND METHODS}

cDNA sequencing. Total RNA was extracted from gills of adult Ostrea edulis exposed to $1 \mathrm{ppm}$ of cadmium according to the guanidium isothiocyanate method (Strohman et al. 1977). cDNA was prepared using a PCR primer corresponding to the first conserved amino acids of the MT peptide sequences from Crassostrea gigas
(Tanguy et al. 2001). First-strand synthesis was performed using an anchored oligo-dT primer and Moloney murine leukemia virus M-MLV reverse transcriptase. Primer sense ATG TCT GAT CCA TGT AAC TG and antisense CGC TCT AGA ACT AGT GGA TC were used for subsequent PCR amplification. Polymerase chain reactions were performed using buffer, $2 \mathrm{mM}$ magnesium ions, Taq polymerase (Promega, $1 \mathrm{U})$, primers (15 pM each), reverse transcription products (200 $\mathrm{ng})$, dNTPs (desoxynucleotide Triphosphate) (2.5 $\mathrm{mM}$ of each) and water. All reactions were performed in a $50 \mu$ final volume. The thermal cycling program used to amplify the MT fragments began with an initial 5 min denaturation at $94^{\circ} \mathrm{C}$ followed by $2 \mathrm{~min}$ annealing at $53^{\circ} \mathrm{C}$ and $40 \mathrm{~s}$ elongation at $72^{\circ} \mathrm{C}$. Then 35 amplification cycles were performed as follows: $94^{\circ} \mathrm{C}$ for $30 \mathrm{~s}, 53^{\circ} \mathrm{C}$ for $40 \mathrm{~s}$ and $72^{\circ} \mathrm{C}$ for $40 \mathrm{~s}$ followed by a final $10 \mathrm{~min}$ at $72^{\circ} \mathrm{C}$. We isolated and sequenced 2 products of about $300 \mathrm{bp}$ (designated OeMTA) and $380 \mathrm{bp}$ (designated OeMTB). The procedure for the generation of the $5^{\prime}$ untranslated region of cDNA was carried out according to the following protocol: first-strand synthesis was performed using an anchored oligo-dT primer and M-MLV reverse transcriptase. The product was purified on a column (Microcon-QIAGEN). An oligo-dA tail was then generated on the $5^{\prime}$ end of the product by the following protocol: $5 \mu \mathrm{l}$ of terminal transferase buffer and $1 \mu \mathrm{l}$ of $10 \mathrm{mM} \mathrm{dATP}$ were added to $18 \mu \mathrm{l}$ of purified product. After $5^{\prime}$ at $95^{\circ} \mathrm{C}, 1 \mu \mathrm{l}$ (100 U) of terminal transferase was added to the mix and placed at $37^{\circ} \mathrm{C}$ for $30 \mathrm{~min}$ and then at $70^{\circ} \mathrm{C}$ for $10 \mathrm{~min}$. Amplification of the specific $5^{\prime}$ untranslated region (UTR) of mRNA was performed using the PCR anchor primer sense CGC TCT AGA ACT AGT GGA TCT $(\mathrm{T})_{10}$ and primer antisense TTT GCA GCT ACA TCC CGA ATC for OeMTA and TTT GCA GGT ACA CCC CGC AGC ACA for OeMTB, designed according to the previous sequence.

Cloning of cDNA and identification of related genes. Complete MT-cDNAs were subsequently amplified using specific primers designed in the untranslated regions. The 2 genomic sequences of Ostrea edulis MT genes were obtained by PCR amplification of isolated DNA using the primer sense CTT TTT TTT CTT CTT TGT ATT CAT TAT TC and primer antisense GAC TAA GAA TGT GCG TTA TTC TT, respectively, for OeMTA, and primer sense CTT TTT TTT TCT TTA TTT ACT TTT CAA CAC and antisense TCA TAA ACA GAA ACA CGG AAT GT, respectively, for OeMTB. Subsequently, the PCR products of cDNAs and genomic DNA were inserted into the pGEM-T vector (Promega, Madison). The inserts were sequenced by extension from both ends using T7 and Sp6 universal primers, and internal sense and antisense primers for genomic inserts (T7 Sequencing Kit, Amersham Pharmacia Biotech). 
Southern blots. DNA of Ostrea edulis was extracted from the gills of 1 freshly opened oyster, and $10 \mu \mathrm{g}$ of DNA were digested to completion with $20 \mathrm{U}$ of various restriction enzymes (EcoRI, HindIII and HaeIII) and separated by agarose gel electrophoresis $(1 \%$ Tris acetate EDTA gel). The fragments were then transferred to nylon membranes, Hybond N+ (Amersham Pharmacia Biotech). Hybridisations were carried out with a randomly-primed OeMTA-cDNA probe radiolabeled with $\left[\alpha{ }^{32} \mathrm{P}\right] \mathrm{dCTP}$ using standard procedures (megaprime DNA labeling, Pharmacia). The MT probe was a 430 bp cDNA (ApaI-PstI fragment of pGEM containing OeMTA-cDNA) encompassing the total coding sequence. Southern blot hybridisation was performed at $65^{\circ} \mathrm{C}$ followed by 2 washes at room temperature in $2 \times \mathrm{SSC}$, followed by 2 washes in $2 \times \mathrm{SSC}$ with $0.1 \%$ sodium dodecyl sulfate at $65^{\circ} \mathrm{C}$, and a final wash in $0.1 \times \mathrm{SSC}$.

Sequence analysis. Sequence analysis and multiple alignments were performed using the FASTA program (Pearson \& Lipman 1988).

Experimental design. European flat oysters Ostrea edulis ( $2 \mathrm{yr}$ old, 6 to $8 \mathrm{~cm}$ in length) were purchased from an oyster farm at Mont Saint-Michel Bay (France) and maintained in aerated filtered seawater before experimentation. Groups of 30 oysters were then exposed to 2 metal elements, 1 essential (copper as $\mathrm{CuCl}_{2}$ ) and 1 toxic (cadmium as $\left.\mathrm{CdCl}_{2}\right)$, at individual concentrations of $0.4 \mu \mathrm{M}$, and in a mixture of $0.2 \mu \mathrm{M}$ each, for $36 \mathrm{~d}$. A group of 30 oysters was maintained in seawater without added metal as a control. The seawater was changed every $2 \mathrm{~d}$ and oysters were fed with microalgae every $2 \mathrm{~d}$. Groups of 3 oysters were collected $0,6,12,21,28$ and $36 \mathrm{~d}$ after contamination for both RNA and protein samples.

DNA was extracted from the gills of 2 natural populations of Ostrea edulis collected from 2 sites that presented different physicochemical characteristics, especially in regard to their metal concentration: Thau (Mediterranean coast, France, $\mathrm{n}=50, \mathrm{Hg}=0.4 \mathrm{\mu g} \mathrm{g}^{-1}$ sediment, $\mathrm{Cd}=1.3 \mu \mathrm{g} \mathrm{g}^{-1}$ sediment, $\mathrm{Pb}=60 \mu \mathrm{g} \mathrm{g}^{-1}$ sediment) and La Rochelle (Atlantic coast, France, $\mathrm{n}=$ $40, \mathrm{Hg}=0.31 \mathrm{mg} \mathrm{kg}^{-1}$ dry tissue weight, $\mathrm{Cd}=5.55 \mathrm{mg}$ $\mathrm{kg}^{-1}$ dry tissue weight, $\mathrm{Pb}=1.68 \mathrm{mg} \mathrm{kg}^{-1}$ dry tissue weight) (metal concentration data provided by RNO [National Observation Network], Institut Français de Recherche pour l'Exploitation de la Mer [IFREMER], France).

Expression study. Reverse transcription and PCR using specific primers from the $5^{\prime}$ and $3^{\prime}$ untranslated region of the MT variants were performed on $0.1 \mu \mathrm{g}$ of total RNA extracted from the gills and digestive gland sampled from oysters (see foregoing subsection). RNA extractions were performed according to the protocol described above.
Primers used for polymerase chain reactions were the primer sense ATG TCT GAT CCT GTA CTT GCA AG and antisense TTT GCA GCT ACA TCC CGA ATC AG for OeMTA and primer sense ATG TCT GAT CCA TGT AAC TGC AAA and antisense TTT GCA GGT ACA CCC CGC AGC ACA for OeMTB. All reactions were performed in a $25 \mu \mathrm{l}$ volume. The thermal cycling program used to amplify the metallothionein fragments was an initial 5 min denaturation at $94^{\circ} \mathrm{C}$, 2 min at $53^{\circ} \mathrm{C}$, and $40 \mathrm{~s}$ at $72^{\circ} \mathrm{C}_{i} 35$ to 45 amplification cycles were performed as follows: $94^{\circ} \mathrm{C}=30 \mathrm{~s} ; 53^{\circ} \mathrm{C}=$ $40 \mathrm{~s}$, and $72^{\circ} \mathrm{C}=30 \mathrm{~s}$, followed by a final step of $10 \mathrm{~min}$ at $72^{\circ} \mathrm{C}$. PCR products were visualized on Tris-borateEDTA $1 \%$ agarose gel with ethidium bromide under UV.

PCR-SSCP analysis. PCR was performed on both Exon 2 and 3 of OeMTA and oeMTB, but not on Exon 1 because of the small size of this exon in both genes. Exon 2 of the OeMTA gene was amplified using the primer sense CTA ATT TAC ATT TTT CTC TCT AGC GG and antisense CCT TTC ATT CCC TAA ATA ACT TAC TG. Exon 2 of the OeMTB gene was amplified using the primer sense GTA TAC ACT TTT CTT TGT AGC AGG AA and antisense AAA ATA AAT AGT GTG TAA AAA CTT GC. Exon 3 of the OeMTA gene was amplified using the primer sense CTA ATT TTA CTC CTT CCA ACA GGT AC and antisense CAG GCG ACC ATT AAT TCA CTA TTT GC. Exon 3 of the OeMTB gene was amplified using the primer sense TAT TTA TAA TCT TTT CAG CAG GTT TC and antisense CAT GCA ACC ATT TAT TCA CTA TTT GC. All PCR amplifications were performed in a $25 \mu$ l volume with $1 \times$ UptiTherm DNA polymerase buffer containing $2 \mathrm{mM} \mathrm{MgCl} 2,200 \mu \mathrm{M}$ dNTPs 10 pmol of each primer, $0.5 \mathrm{U}$ of UptiTherm DNA polymerase (Interchim), and about $100 \mathrm{ng}$ of total genomic DNA. After an initial 2 min denaturation at $95^{\circ} \mathrm{C}, 35$ amplification cycles were performed as follows: $30 \mathrm{~s}$ at $94^{\circ} \mathrm{C}, 30 \mathrm{~s}$ at $51^{\circ} \mathrm{C}$, $30 \mathrm{~s}$ at $72^{\circ} \mathrm{C}$, with a final $5 \mathrm{~min}$ at $72^{\circ} \mathrm{C}$. A volume of $30 \mu \mathrm{l}$ of low ionic-strength loading buffer $\left(100 \mathrm{~g} \mathrm{l}^{-1}\right.$ saccharose, $0.1 \mathrm{~g} \mathrm{l}^{-1}$ bromophenol blue and $0.1 \mathrm{~g} \mathrm{l}^{-1}$ xylene cyanol) were then added to the PCR products, heated for $5 \mathrm{~min}$ at $97^{\circ} \mathrm{C}$, and rapidly chilled on ice to melt and retain single-strand DNA. After loading on a neutral $12 \%$ polyacrylamide gel $(37.5: 1$, acrylamide: bisacrylamide), the samples were electrophoresed at constant voltage $(120 \mathrm{~V})$ in $0.6 \times$ TBE buffer $(50 \mathrm{mM}$ Tris, $40 \mathrm{mM}$ boric acid, $0.5 \mathrm{mM}$ diNaEDTA, $\mathrm{pH}$ 5.5) for $20 \mathrm{~h}$ at $4^{\circ} \mathrm{C}$. After electrophoresis, the gels were stained by ethidium bromide and visualised by UV.

Protein extraction. On Days 0, 6, 12, 21, 28 and 36 of the experiment, the gills and digestive gland from exposed and control oysters ( $\mathrm{n}=3$ for each sample) were collected and homogenised in protein extraction buffer according to the protocol described by Tenden- 
gren et al. (1999): $150 \mathrm{mM} \mathrm{NaCl}, 10 \mathrm{mM} \mathrm{NaH} \mathrm{PO}_{4}$, $1 \mathrm{mM}$ phenylmethanesulfonyl fluoride, $\mathrm{pH}=7.2$ ). The samples were then centrifuged at $11000 \mathrm{~g}$ for $10 \mathrm{~min}$ at $4^{\circ} \mathrm{C}$, and the supernatant fractions containing proteins were collected in fresh tubes. Total protein was quantified using the $\mathrm{D}_{\mathrm{c}}$ Protein Assay Kit (BioRad) with bovine serum albumin (Sigma) as the standard. Optical density (OD) was measured at $620 \mathrm{~nm}$ with a microplate reader.

Metal analysis. Pools of gills (100 mg) excised from 3 oysters on Days $0,6,12,21,28$ and 36 of the experiment were mineralised with suprapure nitric acid. Concentrations of copper and cadmium were measured by a potentiometric stripping method (Riso et al. 1997) previously validated on tissues (Chausson et al. 2001).

OeMTA and OeMTB recombinant proteins (see subsection 'Recombinant DNA manipulations') were purified using TALON metal affinity resin (Clontech Laboratories) according to the manufacturer's instructions, and were then mineralised with superpure nitric acid. Concentrations of copper were measured in each protein sample by the potentiometric stripping method.

Recombinant DNA manipulations. The metallothionein OeMTA and OeMTB cDNAs cloned in pGEM-T vector (Promega) were amplified from the ATG start codon to the last AAA codon to incorporate the recognition sequence for ECoRI using the common primer sense CCC GAA TTC ATG TCT GAT CCA TGT AA, and the specific primers antisense GGG GGA ATT CTT TGC AGC TAC ATC CCG for OeMTA and GGG GGA ATT CTT TGC AGG TAC ACC CCG C for OeMTB. Reaction mixtures included 20 pmol of each primer, $20 \mathrm{ng}$ of each cDNA template, $100 \mu \mathrm{M}$ dNTPs, $2 \mathrm{mM} \mathrm{MgCl} \mathrm{M}_{2} 1 \times \mathrm{Taq}$ polymerase buffer $1 \mathrm{U}$ of Taq polymerase in $50 \mu \mathrm{l}$ total volume. The mixture was preincubated for $5 \mathrm{~min}$ at $94^{\circ} \mathrm{C}$ followed by amplification for 35 cycles: $94^{\circ} \mathrm{C}$ for $30 \mathrm{~s}, 55^{\circ} \mathrm{C}$ for $30 \mathrm{~s}$, and $72^{\circ} \mathrm{C}$ for $30 \mathrm{~s}$. The PCR product was gel-purified using the GeneClean III kit (Bio 101) and digested with EcoRI. The pET20B plasmid was then restricted with EcoRI, gel-purified, and the ends dephosphorylated. The cDNA was ligated with the plasmid and the resulting product was used to transform competent Escherichia coli DH5 $\alpha$ using the protocol previously described by Hanahan (1983). The transformation mixture was plated on LB agar containing ampicillin at $100 \mathrm{~g} \mathrm{~m}^{-1}$, and 6 colonies were screened by EcoRI restriction digestion of alkaline lysis plasmid minipreparations. We then used 1 positive clone of each OeMTA and OeMTB to transform the protease-deficient competent E. coli strain BL21(DE3)pLys (Promega) according to the manufacturer's instructions. BL21(DE3) containing OeMTA and OeMTB cDNA were cultured in LB medium containing $100 \mathrm{\mu g} \mathrm{ml}^{-1}$ ampicillin at $37^{\circ} \mathrm{C}$. Pro- tein expression was induced at $\mathrm{OD}_{600}=1$ with the addition of isopropyl $\beta$-D-thiogalactoside to $2 \mathrm{mM}$. Copper was then added to the culture at a final concentration of $0.5 \mathrm{mM}$.

ELISA. Microtiter plates were coated with $20 \mu \mathrm{g}$ well $^{-1}$ of total proteins extracted from the gills and digestive gland of experimentally exposed oysters. MT concentrations were quantified by ELISA developed on the Pacific oyster Crassostrea gigas using rabbit anti-CgMT1 IgG and recombinant CgMT1 as standard (Boutet et al. 2002). The cross-reactivity of the rabbit anti-CgMT1 IgG and recombinant OeMTA and OeMTB was tested before application to tissue samples. The standard curve used in our experiment originated from OeMT recombinant proteins and was similar to those obtained with CgMT recombinant protein.

Nucleotide sequence accession numbers. The sequency of OeMTs genes reported in this study will appear in the DDJB/EMBLGENBANK data base under accession numbers AJ 306365 and AJ 306366.

Statistical analysis. The rates of metal and MT accumulation during the experiment were analysed by analysis of covariance (ANCOVA, $\alpha=0.05$ ) and a $\chi^{2}$-test $(\alpha=0.05)$ using CSS Statistica Statsoft Software.

\section{RESULTS}

\section{MT-cDNA isolation}

We isolated 2 cDNA using Primers P1 and P2. These products correspond to partial cDNA fragments of 300 and $380 \mathrm{bp}$, respectively, and their sequencing revealed that they contained characteristic Cys-X-Cys motifs. The 2 MT variants designated OeMTA and OeMTB contained an open reading frame (ORF) of 225 and $216 \mathrm{bp}$, respectively, and included a 5' UTR of 93 and $83 \mathrm{bp}$ and a 3'UTR of 88 and $160 \mathrm{bp}$, respectively. The $2 \mathrm{MT}$ variants differed in the number of amino acid residues: 74 for OeMTA and 71 for OeMTB and in the length of their $3^{\prime}$ and $5^{\prime}$ UTR sequence, the OeMTA sequence differing from OeMTB by deletions in the $3^{\prime} \mathrm{UTR}$.

\section{Organisation of OeMT genes}

The Ostrea edulis MT genes corresponding to the 2 MT-cDNA fragments were also isolated using primers from 5'UTR and 3'UTR and sequenced (Figs. 1 $\& 2$ ). The OeMTA and OeMTB genes span 943 and $1538 \mathrm{bp}$ from the beginning of the 5'UTR to the polyadenylation site, respectively. The sequence of OeMTA gene contains 3 coding exons of 46 (18 bp from the 5'UTR), 117 and 188 (108 bp from the 3'UTR) 
bp separated by 2 introns of 81 and $265 \mathrm{bp}$. The sequence of the OeMTB gene contains 3 coding exons of 46 (18 bp from the 5'UTR), 114 and 234 (160 bp from the 3'UTR) bp; the 2 introns are 90 and $99 \mathrm{bp}$. All the intron borders of $O$. edulis MT start and end with the consensus GT and AG splicing signals. A supplementary noncoding exon of 76 and $74 \mathrm{pb}$ for OeMTA and OeMTB, respectively, which corresponds to a part of the $5^{\prime} \mathrm{UTR}$, was observed for the 2 genes.

The MT peptide sequence deduced from the nucleotide sequence shows differences between OeMTA and OeMTB. The OeMTA sequence contains
74 amino acid residues including 21 Cys residues, organized in 9 Cys-X-Cys, 1 Cys-X-X-Cys and 6 Cys$\mathrm{X}-\mathrm{X}-\mathrm{X}$-Cys amino acid motifs. The OeMTB sequence contains 71 amino acid residues including 18 Cys residues, organized in 7 Cys-X-Cys, 1 Cys-X-X-Cys and 4 Cys-X-X-X-Cys amino acid motifs. The amino acid sequences of OeMTs were compared to other known sequences from molluscs using the ALIGN program (Myers \& Miller 1988). Crassostrea gigas and C. virginica showed the highest percentage of identity, with 67.5 and $54 \%$ amino acid identity for OeMTA and OeMTB, respectively, Mytilus edulis displayed

\begin{abstract}
СтTTTTTTTTCTTTATTTACTTTTCAACACAAACACTCTTTGTGAAGCAGATTGAACAACCTTCCTAATCAAAGG TATGTTTTTTTTTTATCTTCGTGTTGTATACTGCTATACATTATTACACATCATAATGAATATTTGGAGAACGT GTGCATACACATAAAAATATTCAATATCGGAAGGAAACGTGGTTATTTGTGAATTTAGATGTAGTATATTCAATC
\end{abstract} TGGTTTAACATTTTTGCAGCAAAGAGGTGCTTAACTGCATATTTTATTGTCATCTCAGTGTCAGAAAATTTTTCA TTTATTATCTGCTGTTAAATGAGTAAATTAAACAAATAATCTCTTTTTGATTTAGAAAAAAGTATGATTTTTAA AATAGTTTTGCTTTCAAAGAAAATATTTCTTTAACCAAATGTGTTTATTCTTATCGCGTCAATCTCAAGGAAGAT AAATATCGTTACCAGTCGCTGATTGAGTTGATAATGCTTGTGTTGTGACATGCGTTCTTTGCCGAACGCGCCAAA ACTTTTCGCGGCAGCTTCAAGGTTTCTTACGTCTTCCAGAGATAAATTCGTAACAGTGCTCGTATGAGTTGATAA TCTTTGTGTTTGTTGACATGCGTCTTTCCTGAATCCGCCCTTTAAGCTATACATTTGCACACGGAACTGTATACT TCAATCGATTATTTGCACACGGTACTGAATAGTTGTCTATCGTGTGGCAAACGAACTAAATAAACTTCATTCATC TTGTTTTGAGCAACAAACACCACTTTCCTCAAGGAATTATTTGCACTTCTAATTAAAGGTCCCTTCGGCTATGTA TTATTTTATGCTCAATTAgTGGAAGAAGATACTACATAAATGTTAAATATATTGCTGTCATACCACAATTAACA AAATTCTAGTGACTGAATCATTTTTATTGAAATTAATTTTTAAAATTCTTTCAGAATTCCACTTTAAGAAAAAT $\longrightarrow \longrightarrow \quad \mathbf{M}$ GTCTGATCCATGTAACTGCCAAAAAATAAGTAATTATTAATTTTAATGATTAATCCAGTTATCGCTATCCATTG $\begin{array}{lllllllllllllll}S & D & P & C & N & C & Q & K & R\end{array}$ TGAGACTGAATGTACAATGTATACACTTTTCTTTGTAGCAGGAAATTGTCAGTGTTCAGGCATCTGTCCCTCCAC

$$
\begin{array}{lllllllllllllllll}
N & C & \& & C & S & G & I & C & P & S & T
\end{array}
$$
TGGGTGTAATTTGCTTCTGGGTGAAATGTGTAGCCGGATGTAAATGTCCCGGATGTAAGATTGTAAATACAGT $\begin{array}{llllllllllllllllllllllllll}G & C & K & C & A & S & G & C & K & C & V & A & G & C & K & C & P & G & C & K & I & V & K & T & V\end{array}$ GGCAAGTTTTTACACACTATTTATTTTCAATTTCTTACCGAAAAGATGAAATTCCGTTAATTTTCATAACTCTGT A $S$

TTACAGTATATTTATAATCTTTTCAGCAGGTTTCTGTGCATACGGAATAGAGTGTATCCGACCTGTCACTTGCAA

$$
\begin{array}{lllllllllllllllll} 
& F & C & A & Y & G & I & E & C & I & R & P & V & T & C & K
\end{array}
$$

ATGTGCTGCGGGGTGACCTGCAAATAGTGAATAAATGGTTGCATGAAAAGACATCATTCATTTGTAAATAGTGT

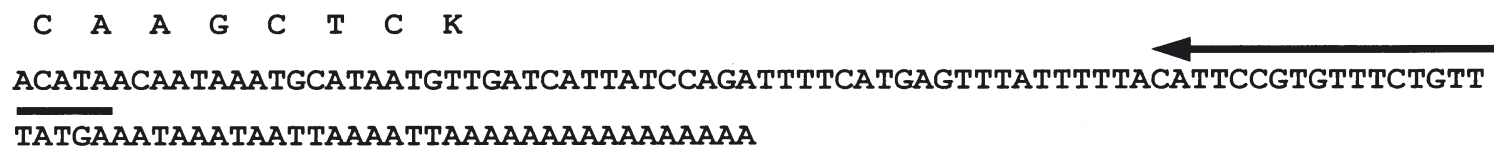

Fig. 1. Ostrea edulis. Nucleotide sequence of MTA gene; 5' and 3' untranslated regions and exons in bold characters; predicted amino acid sequence indicated above corresponding bases. Oligonucleotides used for PCR-amplification are indicated by arrows 


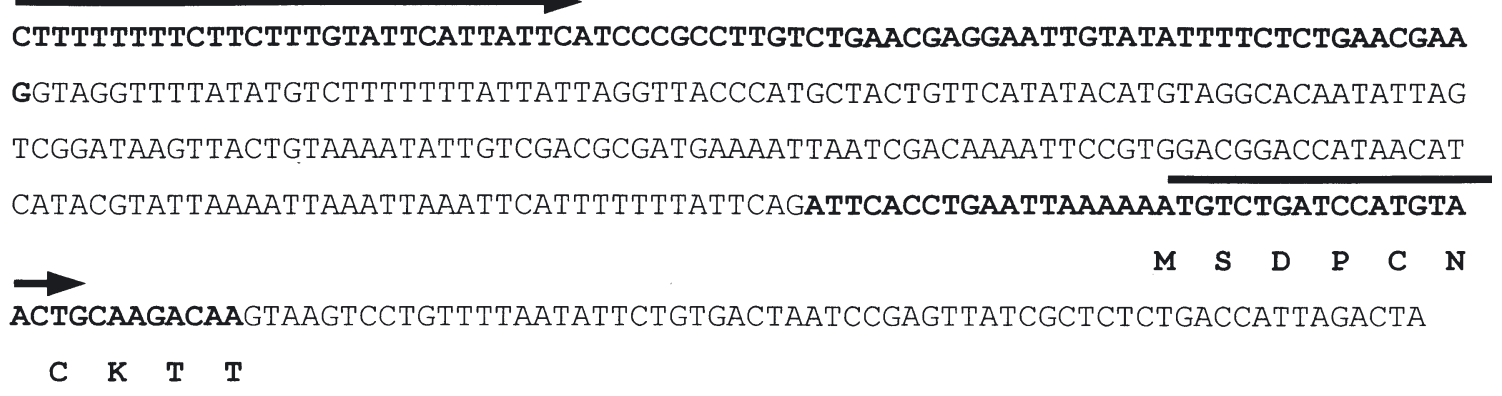

ATTTACATTTTTCTCTCTAGCGGGAAATTGTCTGTGTTCAGACACCTGTCCATCCACTGGGTGTAACTGTGCTTC $\begin{array}{llllllllllllllllll}G & N & C & L & C & S & D & T & C & P & S & T & G & C & N & C & A & S\end{array}$ TGGGTGTAAATGTGGAGCCGGCTGTAAATGTCCCGGATGTCAGATTGTTTGTAAATGCAACAGTAAGTTATTTAG $\begin{array}{llllllllllllllllllllllllllllll}G & C & K & C & G & A & G & C & K & C & P & G & C & Q & I & V & C & K & C & N & S\end{array}$ GGAATGAAAGGGAAAAAAAACAACAGAAAAAAAGCCAACCTGAAAACTGCATCGTTGCGCTGAAGGCAAAGTTTT CCGTGTTTTTGGTTTTTGGTTTACTTCCATCCAATGGTTTTTTTATTAAGTTTAGTCCTTATAAATTCCTTATTA ATTTCATCAAGACTATGAATATTAAAgGCTTTATTAATCTAAAATGTTTTGACCATTCGAAAAGACGGAATTCT GCGAACTAATTTACTCCTTCCAACAGGTACCTGCGCATGCGGAGTAGGATGTACTGGACCTGACACTTGCAAAT $\begin{array}{rrrrrrrrrrrrrrrrr}\text { T } & \text { C } & \text { A } & \text { C } & \text { G } & \text { V } & \text { G } & \text { C } & \text { T } & \text { G } & \text { P } & \text { D } & \text { T } & \text { C } & \text { K } & \text { C } \\ \text { GTGCTGCTGATTCGGGATGTAGCTGCAAATAGTGAATTAATGGTCGCCTGAAAAGTCATCATTCATTTGTAAATA }\end{array}$

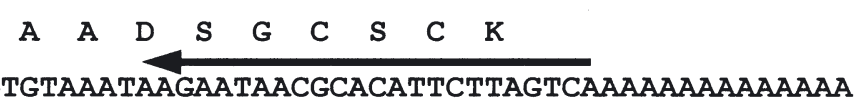

Fig. 2. Ostrea edulis. Nucleotide sequence MTB gene; 5' and $3^{\prime}$ untranslated regions and exons in bold characters; predicted amino acid sequence indicated above corresponding bases. Oligonucleotides used for PCR-amplification are indicated by arrows

$58.7 \%$ for OeMTA and $45.8 \%$ for OeMTB. The percentage identity observed reflects phylogenetic distances between these molluscs, and the alignment shows a relatively conserved arrangement of the Cys motifs. The 2 OeMT sequences, as is true in other molluscs, are characterised by both a lack of CysCys motifs and the presence of a conserved pattern Cys-XCys-X-X-X-Cys-Thr-Gly-X-X-X-Cys-X-Cys-X(n)-Cys$\mathrm{X}$-Cys-Lys, except for OeMTB where the typical motif Thr-Gly-X-X-X- is replaced by Ile-Arg-X-X-X(Figs. 1 \& 2).

Southern blot analysis of Ostrea edulis DNA extracted from 2 oysters, digested with various restriction enzymes (ECoRI, HindIII and HaeIII) and probed with OeMTA-cDNA, revealed several patterns for the fragments (Fig. 3). The absence of EcoRI, HindIII and HaeIII sites from the OeMTA gene sequence and the presence of 1 EcoRI site in the OeMTB sequence associated with the presence of 2 to 3 bands in the Southern blot, showed that at least 2 MT genes are present in the genome. Southern blots also demonstrated the existence of a restriction fragment length polymorphism (RFLP) in individuals for the 3 enzymes studied.

\section{Properties of OeMTA and OeMTB proteins}

The direct quantification of metal-ions bound to OeMTA and OeMTB performed on the 2 purified recombinant proteins using the potentiometric stripping method showed that OeMTA and OeMTB were able to bind about 3.03 and $2.42 \mathrm{~mol}$ of copper $\mathrm{mol}^{-1}$ of protein, respectively. These results indicate that OeMTA has a higher metal-ion binding capacity than OeMTB.

\section{Metal analysis and quantification of metallothioneins in Ostrea edulis by ELISA}

Copper and cadmium concentration in gills of oysters experimentally exposed to $\mathrm{Cu}^{2+}$ and $\mathrm{Cd}^{2+}$ showed a significant time-dependent increase (compared with controls) during the $36 \mathrm{~d}$ of the experiment. Copper concentrations in the gills of oysters exposed to $0.4 \mu \mathrm{M}$ of $\mathrm{Cu}^{2+}$ increased from 0.17 to $0.86 .10^{-6} \mathrm{M} \mathrm{g}^{-1}$ wet tissue wt $\left(\mathrm{R}^{2}=0.812\right)$ (Fig. 4A). Contamination with $0.4 \mu \mathrm{M} \mathrm{Cd}^{2+}$ (Fig. 4B) resulted in an increase of Cd con- 
centration in the gills from $<0.01$ to $0.21 .10^{-6} \mathrm{M} \mathrm{g}^{-1}$ wet wt $\left(\mathrm{R}^{2}=0.979\right)$. The concentration in the gills of oysters exposed to a mixture of the 2 metals increased from 0.17 to $0.36 .10^{-6} \mathrm{M} \mathrm{g}^{-1}$ wet wt for $\mathrm{Cu}$ and from 0.01 to $0.17 .10^{-6} \mathrm{M} \mathrm{g}^{-1}$ wet wt for $\mathrm{Cd}\left(\mathrm{R}^{2}=0.105\right.$ and $\mathrm{R}^{2}=$ 0.919, respectively) (Fig. 4C,D).

Application of an ELISA test to protein samples extracted from gills and digestive glands of exposed and control oysters showed that MT levels did not vary significantly during the experiment, regardless of treatment (Fig. 5A,B). However, for all treatments, the mean MT level was greater in the digestive gland than in the gills. The antibody developed with recombinant Crassostrea gigas MT1 was first tested with recombinant OeMTA and OeMTB and showed a positive cross-reactivity with these 2 proteins. Comparison of OD values for identical CgMT and OeMT concentrations showed no differences in the ELISA.

\section{Expression and polymorphism of OeMT genes}

RT-PCR was applied to both MTA and MTB genes to samples exposed to metal $\left(\mathrm{Cu}^{2+}\right.$ and $\left.\mathrm{Cd}^{2+}\right)$ and to controls. No clear differences in expression of these 2 genes was observed as a function of exposure time. Both tissues (gills and digestive gland) express MTA and MTB genes, but MTA seems more expressed than

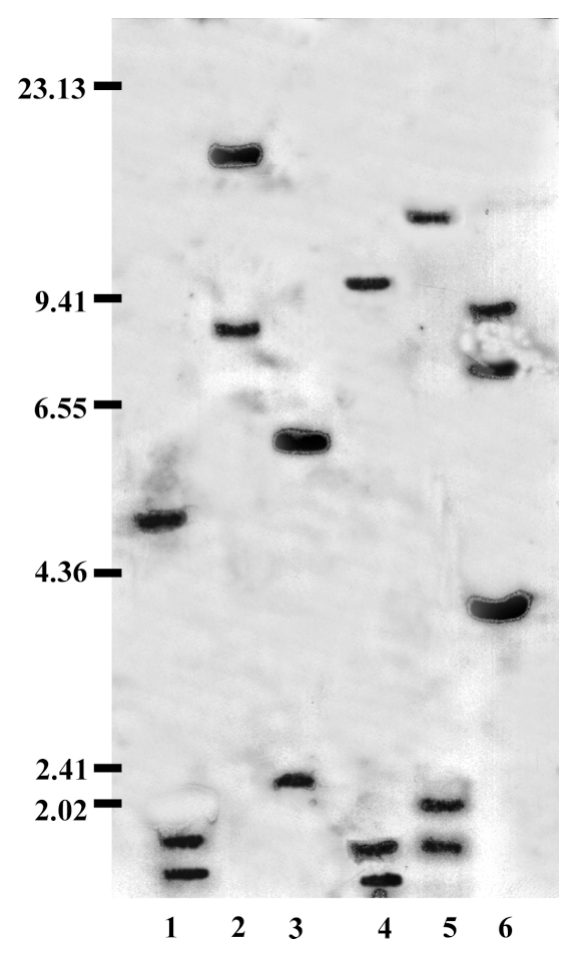

Fig. 3. Ostrea edulis. Gel blots of restriction digests of genomic DNA extracted from 2 adults and digested with ECoRI (Lanes 1 and 4), HindIII (Lanes 2 and 5), HaeIII (Lanes 3 and 6) and then electrophoresed and probed with OeMTA cDNA at high stringency. Marker was fragments of HindIIIdigested $\lambda$
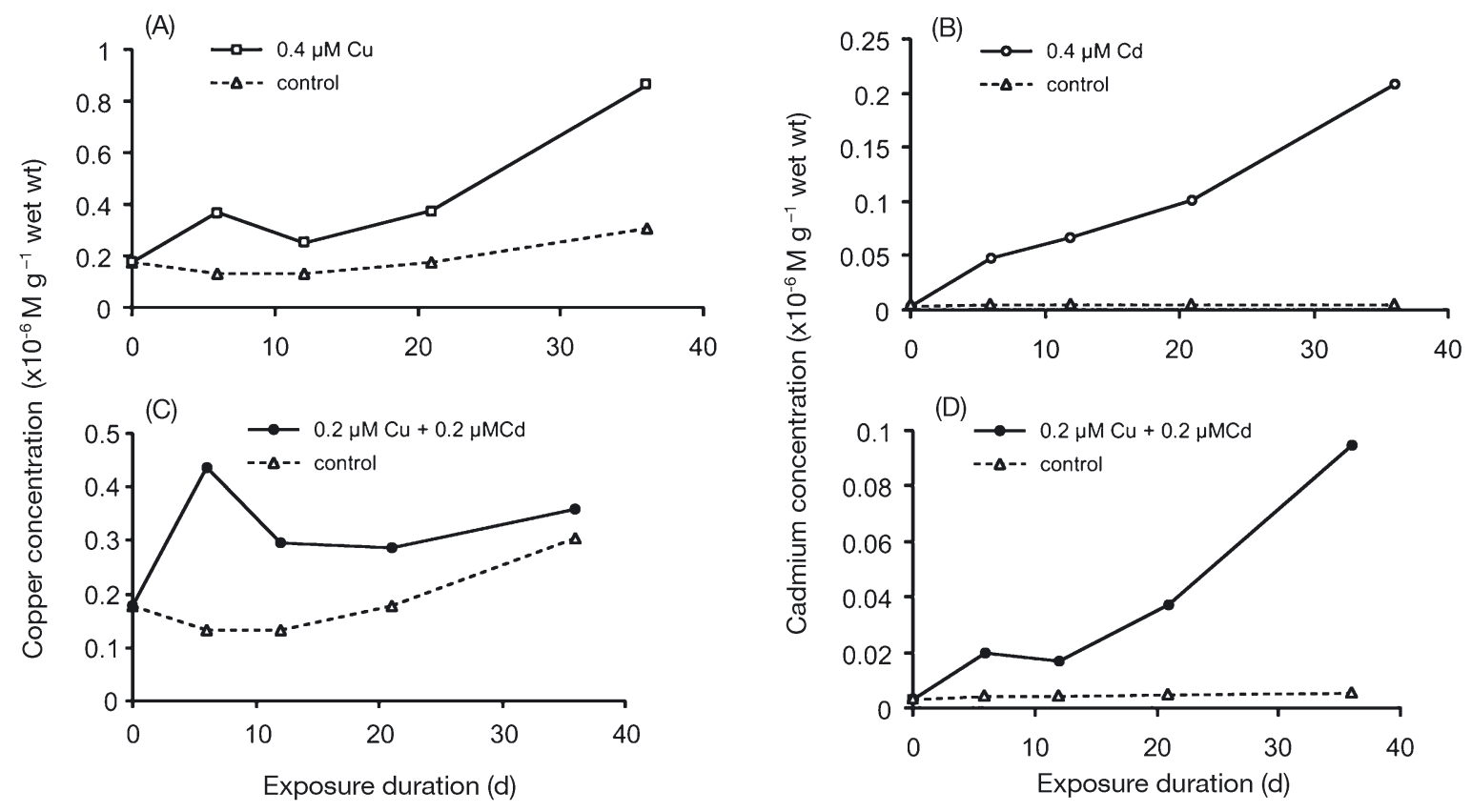

Fig. 4. Ostrea edulis. Metal concentrations determined by potentiometric stripping analysis in gills of oysters exposed to (A) copper, (B) cadmium and $(\mathrm{C}, \mathrm{D})$ mixture of copper and cadmium at different concentrations. Each data point corresponds to measurement of pooled tissue from 3 individuals 

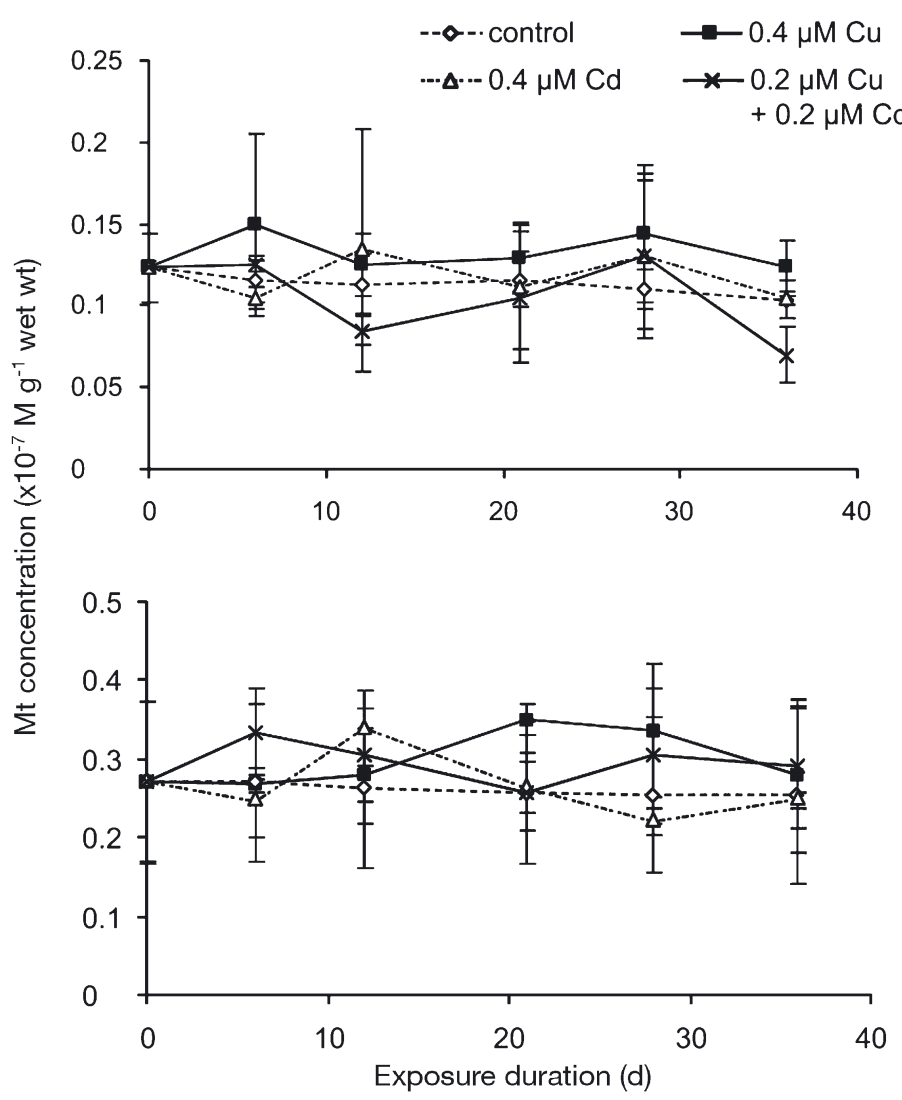

Fig. 5. Ostrea edulis. Quantification of metallothioneins (MT) by ELISA in (A) gills and (B) digestive gland of oysters exposed to copper, cadmium and a mixture of copper and cadmium. Each data point is mean $( \pm \mathrm{SE})$ of 3 individuals

MTB, with 45 cycles being necessary to amplify MTB compared to only 35 for MTA for the same amount of RNA.

The PCR-SSCP performed on the second and the third coding exon of the OeMTA and OeMTB genes did not reveal any polymorphism in the 2 populations studied.

\section{DISCUSSION}

Herein, we have reported the cloning of 2 MT genes from the European flat oyster Ostrea edulis. These are the first genomic sequences coding for metallothioneins described for this species. Our results are in accordance with those previously obtained for $O$. edulis by SDS-PAGE (sodium dodecyl sulfate-polyacrylamide gel electrophoresis), which detected 2 principal isometallothioneins in all organs of the oyster (Alonso \& Martin-Mateo 1996). The 2 O. edulis MT genes are characterised by a structure of 3 coding exons and a first completely non-coding exon. The organisation of the 3 coding exons has been classically described for MTs, whereas additional non-coding exons have been observed in only a few organisms, such as the sea urchin Strongylocentrotus purpuratus (Nemer et al. 1991) and the Pacific oyster Crassostrea gigas (Tanguy \& Moraga 2001, Tanguy et al. 2001).

The 2 OeMT sequences exhibited a moderate degree of similarity in terms of both nucleotide and amino acid sequences when compared with each other and with other MT mollusc sequences. However, it is interesting to note that the predicted amino acid sequence of Ostrea edulis MT (as in other mollusks and some other invertebrates such as the crab Cancer pagurus [Overnell et al. 1988], does not contain any Cys-Cys pairs. Although most MT isoforms may differ in amino acid sequence (60 to 75 amino acids) according to species, they generally do not vary in cysteine content (about 18 to 21 cysteine residues) and metalbinding capacity (Winge et al. 1984). With 71 and 74 amino acids, the OeMT genes are close to those found in others mollusc species. Only 1 exception has been observed, namely in Crassostrea gigas, in which the MT2 gene consists of 107 amino acid and 30 cysteine residues (Tanguy \& Moraga 2001).

In mammalian MTs, the 20 cysteine residues are distributed in 2 independent domains: $\alpha$, coded by the 11 first cysteine amino acids, and $\beta$, coded by the 9 final cysteine residues. Similar results were obtained for the sea urchin Strongylocentrotus purpuratus, which showed an inversion of the 2 domains (Riek et al. 1999). In crustaceans, MT from the crab Scylla serrata was analysed by nuclear magnetic resonance and showed the existence of $2 \beta$-domains consisting of 18 cysteine residues present in the coding sequence (Otvos et al. 1985). In previous studies, we discussed the existence of an $\alpha$ and a $\beta$-domain in the MT1 gene of the oyster Crassostrea gigas and the possibility of the presence of a third $\beta$-domain in a particular MT gene, CgMT2 (Tanguy \& Moraga 2001, Tanguy et al. 2001). In the case of the OeMTA gene, the observed characteristics of the coding sequence are comparable to that of CgMT1, suggesting that the domain organisation and the metal-binding capacities are similar. However, 3 cysteine residues are missing from the OeMTB gene compared to OeMTA and others mollusc MT genes. As the involvement of cysteine residues in the metal binding has been widely demonstrated in different species, the absence of these 3 cysteine residues suggests a modification in the 2-domain organisation and in the metal-binding capacity of the resulting OeMTB protein. The determination of copper concentration in both OeMTs revealed that OeMTA was capable of binding about $20 \%$ more of the metal than OeMTB. It has been previously shown that mammalian MTs can bind 6 to $20 \mathrm{~mol}$ of $\mathrm{Cu} \mathrm{mol}^{-1}$ protein, 
and many studies have shown that Cu-MTs contained 12 ions of $\mathrm{Cu}$ (Griffith et al. 1983, Maroni 1990). Our results show a value 2 to 6 times lower that expected. This could be partially explained by a displacement of metals from MTs during the purification of the recombinant protein leading to a decrease in the copper concentration, as shown in others works (Paris-Palacio et al. 2000, Tanguy \& Moraga 2001). In addition, it demonstrates the importance of cysteine residue number to the quantity of metallic ions that can be bound by the metallothioneins. Indeed, the OeMTA protein contains about $16 \%$ more cysteine residues than the OeMTB sequence, about the same as the difference in the metal-binding capacity of the 2 proteins. The existence of an aromatic amino acid (tyrosine), resulting from the mutation of a cysteine residue, in the sequence of OeMTB is also unusual in MTs, and could modify the 3-dimensional structure and other properties of the resulting protein. Moreover, it has been demonstrated that the $\alpha$ and $\beta$ domains of MTs are separated by 2 lysine residues (Otvos et al. 1982). These residues were found in OeMTB, but not in OeMTA, suggesting that other amino acids could be involved in the separation of the 2 domains. The length of the $3^{\prime}$ and $5^{\prime}$ untranslated sequences of the OeMT variants is superior to the range of reported lengths of the MT $5^{\prime}$ and 3 ' ends from other species. The mammalian, fish and oyster MT 5' end varies from 10 to $73 \mathrm{bp}$ (83 and $93 \mathrm{bp}$ in OeMTA) and the 3' end from 110 to $140 \mathrm{bp}$ (88 and $160 \mathrm{bp}$ in OeMTB). The differences in the $5^{\prime}$ and 3' UTR sequences of the 2 Ostrea edulis MT genes could account for differential regulation of the MT transcripts, as previously proposed (Jackson 1993). As found in the 3'UTR of the cDNA encoding the MT20 transcript in the mussel Mytilus edulis (Barsyte et al. 1999), an ATTTTTA motif occurs in the 3'UTR of OeMTB. This motif has been linked to the rapid degradation of some mRNAs in mammals (Nakamaki et al. 1995).

Previous work has demonstrated the presence of the $2 \mathrm{MT}$ isoforms in all organs and in the presence of different metals, such as copper and zinc (Alonso \& Martin-Mateo 1996). All these results suggest that no tissue-specific expression exists for these 2 MTs in $O$. edulis, contrary to other invertebrates including the nematode Caenorhabditis elegans, in which 2 inducible transcription of 2 MT genes occurs exclusively in the intestinal cells of larvae and adults (Freedman et al. 1993), or in the sea urchin Strongylocentrotus purpuratus, where 2 MT genes (MTA and MTB) have shown temporal and tissue-specific expression in the embryo (Nemer et al. 1985, Wilkinson \& Nemer 1987). The expression study we conducted on both MTA and MTB confirmed these results and showed only a difference in terms of RNA content between the 2 genes, OeMTA being more expressed than OeMTB.

Quantification of MTs by ELISA revealed a tissuespecific response: greater MT concentrations were measured in the digestive gland than in the gills for all experiments, as described earlier by Barsyte et al. (1999) Viarengo et al. (1997) Langston et al. (1998). These observations were consistent with the involvement of these 2 tissues in storage and uptake of metals, respectively. We observed that MT concentrations measured in experimentally exposed individuals were not significantly different from the concentrations measured in control animals, despite a significant metal accumulation in the gills. Similar experiments on the Pacific oyster Crassostrea gigas (Boutet et al. 2002) revealed a differential behaviour in terms of MT expression during the metal exposure. Exposure to copper, cadmium, or to a mixture of these 2 metals resulted in increased MT levels in the gills and digestive gland of metal-exposed $C$. gigas. The observation that copper accumulation in individuals exposed to a mixture of copper and cadmium was reduced compared to individuals exposed to copper only, suggests that bioaccumulation for these 2 metals depends on competitive processes. It has also been shown that exposure of the eastern oyster $C$. virginica to moderate cadmium concentrations resulted in induction and increased binding of metals to MT in preference to other ligands (Roesijadi 1992).

The metal detoxification processes in Ostrea edulis are probably partly based on other mechanisms, such as low molecular weight ligands. The involvement of these ligands was described in a previous study on $O$. edulis collected from Restronguet Creek, UK (Frazier \& George 1983). Thus, MTs seem to play only a minor role in metal sequestration in O. edulis. Limited or negligible involvement of MTs in metal-binding has been also reported for other bivalves such as Anodonta cygnea and Unio elongatulus (Cassini et al. 1986, Tallindini et al. 1986) or Macoma balthica (Langston \& Zhou 1987), confirming that metal exposure does not always result in detectable induction, and this suggests that the involvement of MTs in regulation and detoxification is not always consistent. Previous works have also shown that in acute cadmium exposure experiments, Crassostrea virginica presented different cytosolic distribution of cadmium, with a large percentage of the cytosolic cadmium occurring in the very low molecular weight material, $<5 \mathrm{kDa}$ fraction, rather than being associated with the MT complex (Ruddel \& Rains 1975, Simkiss \& Taylor 1989, Engel 1999). The absence of MT induction in $O$. edulis could also reflect an inhibition of protein metabolism by high metal concentration, as reported by other authors (Steiner \& Pickwell 1988, Fernandes \& Henriques 1991). 
In previous works, we showed some polymorphism in the coding sequence of MT genes in the Pacific oyster Crassostrea gigas that could be associated with metal tolerance (Tanguy et al. 2002). In an attempt to identify a potential tolerance to heavy metals, we studied the coding sequence of the 2 MT genes in 2 field populations exposed to various concentrations of heavy metals. Our results showed the absence of genetic divesity in the coding sequence of OeMTA and OeMTB genes. Although only 90 individuals were genotyped in this study, the results suggest either the complete absence or a very low level of coding polymorphism in this species for these genes. Southern blot revealed the existence of an RFLP polymorphism, suggesting the possible use of other kinds of genetic markers. The differences between the 2 oysters could be due to a strong difference in the genetic diversity of the 2 species. Ostrea edulis is currently characterised by low genetic diversity (Le Pennec et al. 1985). Moreover, this species was partly destroyed by a parasitic protozoan Bonamia ostrea along the European coasts in the 1980s, resulting in a further strong reduction in its populations and genetic diversity (Renault et al. 1995). With an age at maturity of $3 \mathrm{yr}$ and a protandrous alternating hermaphrodite type of reproduction, this species also has a limited larvae distribution that contributes to reducing genetic fluxes between populations (Wilson \& Simons 1985).

The present study has provided a new insight into the MT structure and properties of marine molluscs compared to classical MTs described for other invertebrate and vertebrate species. However, MT does not seem to be an appropriate indicator for studing the genetic structure of Ostrea edulis populations, especially after exposure to environmental heavy-metal contamination, because no coding polymorphism is detectable in these genes. The determination of the exact role of these 2 MTs and their regulation processes in $O$. edulis could be the objective of next studies.

Acknowledgements. This research program was supported by the CE FAIR CT98-4129 program: 'Environmental factors and shellfish diseases' and the Région Bretagne. The authors are grateful to Dr. Louis Quiniou for his help with use of the CSS Statistica Statsoft Software, to Monique Briand for editing the graphs and to Professor Susan Ford for English corrections to this manuscript.

\section{LITERATURE CITED}

Alonso JI, Martin-Mateo MC (1996) Induction and characterization of metallothionein in different organs of Ostrea edulis L. Biol Trace Elem Res 53:85-93

Barsyte D, White KN, Lovejoy DA (1999) Cloning and characterization of metallothionein cDNAs in the mussel Mytilus edulis L. digestive gland. Comp Biochem Physiol C 122: 287-296
Boulanger Y, Goodman CM, Forte CP, Fesik SW, Armitage IM (1983) Model for mammalian metallothionein structure. Proc Natl Acad Sci USA 80:1501-1505

Boutet I, Tanguy A, Auffret M, Riso R, Moraga D (2002) Immunochemical quantification of metallothioneins in marine molluscs: characterisation of a metal exposure bioindicator. Environ Toxicol Chem 21:1009-1014

Cassini A, Tallindini L, Favero N, Albergoni V (1986) Cadmium bioaccumulation studies in the freshwater molluscs Anodonta cygnea and Unio elongatulus. Comp Biochem Physiol C 84:35-41

Chausson F, Bridges CR, Sarradin PM, Green BN, Riso R, Caprais JC, Lallier FH (2001) Structural and functional properties of hemocyanin from Cyanagraea praedator, a deep-sea hydrothermal vent crab. Proteins 45:351-359

Engel DW (1999) Accumulation and partitioning of metals in the American oyster Crassostrea virginica. Mar Environ Res 47:89-102

Fernandes JC, Henriques FS (1991) Biochemical, physiological and structural effects of excess copper in plants. Bot Rev 57:246-273

Frazier JM, George SG (1983) Cd kinetics in oysters-a comparative study of Crassostrea gigas and Ostrea edulis. Mar Biol 76:55-61

Freedman JH, Slice LW, Dixon D, Fire A, Rubin CS (1993) The novel metallothionein genes of Caenorhabditis elegans. Structural organization and inducible, cell-specific expression. J Biol Chem 268:2554-2564

Furey WF, Robbins AH, Clancy LL, Winge DR, Wang BC, Stout CD (1986) Crystal structure of Cd, Zn, metallothionein. Science 231:704-710

Gedamu L, Varshney U, Jahroudi N, Foster R, Showak NW (1987) Structure and expression of the human metallothionein genes. Exper Suppl 52:361-372

Griffith BB, Walters RA, Enger MD, Hildebrand CE, Griffith JK (1983) cDNA cloning and nucleotide sequence comparison of Chinese hamster metallothionein I and II mRNAs. Nucleic Acids Res 11:901-910

Hamer DH (1986) Metallothioneins. Annu Rev Biochem 55: 913-951

Hanahan D (1983) Studies on transformation of Escherichia coli with plasmids. J Mol Biol 16:557-580

Hunziker PE, Kaur P, Wan M, Kanzig A (1995) Primary structures of seven metallothioneins from rabbit tissue. Biochem J 306:265-270

Jackson RJ (1993) Cytoplasmic regulation of mRNA function: the importance of the 3' untranslated region. Cell 74: 9-14

Kägi JHR (1993) Evolution, structure and chemical activity of class I metallothioneins: an overview. In: Suzuki KT, Imura N, Kimura M (eds) Metallothionein III: biological roles and medical implications, Birkhäuser Verlag, Basel, p 29-35

Karin M (1985) Metallothioneins: proteins in search of function. Cell 41:9-10

Khoo HW, Patel K (1999) Metallothionein cDNA, promoter, and genomic sequences of the tropical green mussel, Perna viridis. J Exp Zool 284:445-453

Kojima Y, Kägi JHR (1978) Metallothionein. Trends Biotech Sci 3:90-93

Langston WJ, Zhou M (1987) Cadmium accumulation, distribution and elimination in the bivalve Macoma balthica: neither metallothionein nor metallothionein-like proteins are involved. Mar Environ Res 21:225-237

Langston WJ, Bebianno MJ, Burt GR (1998) Metal handling strategies in molluscs. In: Langston WJ, Bebianno MJ (eds) Metal metabolism in aquatic environments. Chapman \& Hall, London, p 219-283 
Le Pennec M, Moraga D, Blanc F, Pichot P, Thiriot-Quievreux C (1985) Recherche de différences morphogénétiques, biochimiques et cytogénétiques entre Ostrea edulis sensu stricto et Ostrea edulis 'pied de cheval'. Vie Mar 7:29-39

Maroni G (1990) Animal metallothionein. In: Shaw JA (ed) Heavy metals tolerance in plants: evolutionary aspects. CRC Press, Boca Raton, FL, p 215-232

Myers EW, Miller W (1988) Optimal alignments in linear space. Comput Appl Biosci 4:11-17

Nakamaki T, Imamura J, Brewer G, Tsuruoka N, Koeffler HP (1995) Characterization of adenosine uridine-rich RNAbinding factor. J Cell Physiol 162:484-492

Nemer M, Travaglini EC, Rondinelli E, D'Alonzo J (1984) Developmental regulation, induction, and embryonic tissue specificity of sea urchin metallothionein gene expression. Dev Biol 102:471-482

Nemer M, Wilkinson DG, Travaglini EC (1985) Primary differentiation and ectoderm-specific gene expression in the animalized sea urchin embryo. Dev Biol 109:418-427

Nemer M, Thornton RD, Stuebing EW, Harlow P (1991) Structure, spatial, and temporal expression of two sea urchin metallothionein genes, SpMTB1 and SpMTA. J Biol Chem 266:6586-6593

Otvos JD, Olafson RW, Armitage IM (1982) Structure of an invertebrate metallothionein from Scylla serrata. J Biol Chem 265:6369-6375

Otvos JD, Engeseth HR, Wehrli S (1985) Preparation and ${ }^{113} \mathrm{Cd}$ NMR studies of homogeneous reconstituted metallothionein: reaffirmation of the two-cluster arrangement of metals. Biochemistry 24:6735-6740

Overnell J, Good M, Vasak M (1988) Spectroscopic studies on cadmium (II)- and cobalt (II)-substituted metallothionein from the crab Cancer pagurus. Eur J Biochem 172:171-177

Paris-Palacio S, Biaganti-Risbourg S, Fouley A, Vernet G (2000) Metallothioneins in the liver of Rutilus rutilus exposed to $\mathrm{Cu}^{2+}$. Analysis by metal summation, SH determination and spectrofluorometry. Comp Biochem Physiol C 126:113-122

Pearson WR, Lipman DJ (1988) Improved tools for biological sequence comparison. Proc Natl Acad Sci USA 85: 2444-2448

Peterson MG, Hannan F, Mercer JFB (1988) The sheep metallothionein gene family. Structure, sequence and evolutionary relationship of five linked genes. Eur J Biochem 174:417-424

Renault T, Cochennec N, Grizel H (1995) Bonamia ostrea, parasite of the European flat oyster, Ostrea edulis, does not experimentally infect the Japanese oyster, Crassostrea gigas. Bull Eur Assoc Fish Pathol 15:78-80

Riek R, Prêcheur B, Wang Y, Mackay EA and 5 others (1999) NMR structure of the sea urchin (Strongylocentrotus purpuratus) metallothionein MTA. J Mol Biol 291:417-428

Riso RD, Le Corre P, Chaumery CJ (1997) Rapid and simultaneous analysis of trace metals $(\mathrm{Cu}, \mathrm{Pb}$ and $\mathrm{Cd})$ in seawater by potentiometric stripping analysis. Anal Chim Acta 351: 83-89

Editorial responsibility: Otto Kinne (Editor),

Oldendorf/Luhe, Germany
Roesijadi G (1992) Metallothioneins in metal regulation and toxicity in aquatic animals. Aquat Toxicol (NY) 22:81-114

Ruddell CL, Rains DW (1975) The relationship between zinc, copper and the basophils of two crassostreid oysters, C. gigas and C. virginica. Comp Biochem Physiol A 51: 585-591

Simkiss K, Taylor MG (1989) Convergence of cellular systems of metal detoxification. Mar Environ Res 28:211-214

Steinert SA, Pickwell GV (1988) Expression of heat shock protein and metallothionein in mussels exposed to heat stress and metal ion challenge. Mar Environ Res 24: $211-214$

Strohman RC, Moss PS, Micou-Eastwood J, Spector D, Przybyla A, Paterson B (1977) Messenger RNA for myosin polypeptides: isolation from single myogenic cell cultures. Cell 10:265-273

Tallindini L, Cassini A, Favero N, Albergoni V (1986) Regulation and subcellular distribution of copper in the freshwater molluscs Anodonta cygnea (L.) and Unio elongatulus (Pf.). Comp Biochem Physiol C 84:43-49

Tanguy A, Moraga D (2001) Cloning and characterization of a gene coding for a novel metallothionein in the Pacific oyster Crassostrea gigas (CgMT2): a case of adaptive response to metal-induced stress? Gene 273:123-130

Tanguy A, Mura C, Moraga D (2001) Cloning of a metallothionein gene and characterization of two other cDNA sequences in the Pacific oyster Crassostrea gigas (CgMT1). Aquat Toxicol 55:35-47

Tanguy A, Boutet I, Bonhomme F, Boudry P, Moraga D (2002) Polymorphism of metallothionein genes in the Pacific oyster Crassostrea gigas as a biomarker of metal exposure. Biomarkers 7:439-450

Tendengren M, Olsson B, Reimer O, Brown DC, Bradley BP (1999) Heat pretreatment increases cadmium resistance and HSP70 levels in Baltic sea mussels. Aquat Toxicol 48: $1-12$

Unger ME, Chen TT, Fenselau CC, Murphy CM, Vestling MM, Roesijadi G (1991) Primary structure of a molluscan metallothionein deduced from molecular cloning and tandem mass spectrometry. Biochim Biophys Acta 1074: 371-377

Viarengo A, Ponzano E, Dondero F, Fabbri RA (1997) A simple spectrophotometric method for metallothionein evaluation in marine organisms: an application to Mediterranean and Antarctic molluscs. Mar Environ Res 44:69-84

Wilkinson DG, Nemer M (1987) Metallothionein genes Mta and MTb expressed under distinct quantitative and tissue specific regulation in sea urchin embryos. Mol Cell Biol 7: $48-58$

Wilson JH, Simons J (1985) Gametogenesis and breeding of Ostrea edulis on the west coast of Ireland. Aquaculture 46: 307-321

Winge DR, Nielson KB, Zeikus RD, Gray WR (1984) Structural characterization of the isoforms of neonatal and adult rat liver metallothionein. J Biol Chem 259:11419-11425

Submitted: December 12, 2002; Accepted: May 8, 2003

Proofs received from author(s): July 28, 2003 